\title{
PERAN POSYANDU DALAM PELAYANAN KESEHATAN MASYARAKAT
}

\author{
Erwina Susanti, Wisuda Andeka Marieni, Kosma Heryati \\ Politeknik Kesehatan Kementerian Kesehatan Bengkulu, Jurusan Kebidanan, \\ Jalan Indragiri Nomor 03 Padang Harapan Bengkulu \\ erwinasusanti@gmail.com
}

\begin{abstract}
Elderly health care coverage in Public Health Jalan Gedang as much (81.92\%) and the number of elderly as many as 686 people. Visit the elderly who come to posyandu ranges from 41-53 people per month in 2016. The health center has two IHC Gedang Way consists of IHC Elderly Elderly Serayu Mandiri and Posyandu Elderly Peace. IHC has five cadres and participants 44 people. Elderly Posyandu cadre of Peace has five people, participants lansianya 50 people. IHC Elderly Peace has many achievements than Posyandu Elderly Serayu Mandiri The study design used in this research is descriptive qualitative method. Informants in this study as many as 10 cadres and 1 officer in charge Posyandu program. The study design used in this research is descriptive qualitative method. Knowledge Posyandu Elderly Peace found that IHC Elderly for seniors 60 years and older age range and Posyandu Elderly Serayu Mandiri that Posyandu Elderly age range of 40 years and above. Attitude Posyandu Elderly Peace mostly elderly support and integrated support Serayu Mandiri attitude. Kader Posyandu Elderly Peace and Posyandu Elderly Serayu Mandiri mostly not expect incentives. Kader Posyandu Elderly Peace mostly mentioned five systems the table properly and Posyandu Elderly Serayu Mandiri no mention of five tables with the right system. Expected to conduct refresher training or volunteers to knowledge about Posyandu cadres better, could improve the role in the service of Posyandu.
\end{abstract}

Keywords: Role Kader, Knowledge, Attitudes, Roles, Services, Incentives

Abstrak : Cakupan pelayanan kesehatan lansia Posyandu Lansia di Puskesmas Jalan Gedang sebanyak $(81,92 \%)$ dan jumlah lansia sebanyak 686 orang. Kunjungan lansia yang datang ke posyandu berkisar 41-53 orang per bulan pada tahun 2016. Puskesmas Jalan Gedang memiliki dua Posyandu Lansia terdiri dari Posyandu Lansia Serayu Mandiri dan Posyandu Lansia Damai. Posyandu ini memiliki lima orang kader dan pesertanya 44 orang. Posyandu Lansia Damai ini memiliki kader lima orang, peserta lansianya ada 50 orang. Posyandu Lansia Damai memiliki banyak prestasi dibandingkan Posyandu Lansia Serayu Mandiri. Desain penelitian yang digunakan pada penelitian ini adalah deskriptif dengan metode kualitatif. Informan pada penelitian ini yaitu sebanyak 10 orang kader dan 1 orang petugas penanggung jawab program posyandu lansia. Desain penelitian yang digunakan pada penelitian ini adalah deskriptif dengan metode kualitatif. Pengetahuan kader Posyandu Lansia Damai didapatkan bahwa Posyandu Lansia untuk lansia rentang usia 60 tahun keatas dan kader Posyandu Lansia Serayu Mandiri bahwa Posyandu Lansia untuk rentang usia 40 tahun keatas. Sikap kader Posyandu Lansia Damai sebagian besar mendukung dan Posyandu Lansia Serayu Mandiri sikap tidak mendukung. Kader Posyandu Lansia Damai dan Posyandu Lansia Serayu Mandiri sebagian besar tidak mengharapkan insentif. Kader Posyandu Lansia Damai sebagian besar menyebutkan sistem lima meja dengan benar dan kader Posyandu Lansia Serayu Mandiri tidak ada yang menyebutkan sistem lima meja dengan tepat. Diharapkan bisa melakukan penyegaran ataupun pelatihan kader agar pengetahuan kader mengenai posyandu lansia lebih baik, bisa meningkatkan peran dalam melakukan pelayanan posyandu lansia.

Kata Kunci : Peran Kader, Pengetahuan, Sikap, Peran, Pelayanan, Insentif 
Proporsi penduduk lanjut usia (lansia) yang semakin besar membutuhkan perhatian dan perlakuan khusus dalam pelaksanaan pembangunan. Usia 60 tahun ke atas merupakan tahap akhir dari proses penuaan yang memiliki dampak terhadap tiga aspek, yaitu biologis, ekonomi, dan sosial. Secara biologis, lansia akan mengalami proses penuaan secara terus menerus yang ditandai dengan penurunan daya tahan fisik dan rentan terhadap serangan penyakit. Secara ekonomi, umumnya lansia lebih dipandang sebagai beban daripada sumber daya. Secara sosial, kehidupan lansia sering dipersepsikan secara negatif, atau tidak banyak memberikan manfaat bagi keluarga dan masyarakat. Negara perlu memberikan perlindungan dan pemberdayaan kepada lansia sehingga keberadaannya tidak menjadi beban pembangunan, melainkan dapat berpartisipasi secara aktif dan positif (Badan Pusat Statistik, 2014).

Jumlah lansia di Indonesia mencapai 20,24 juta jiwa, setara dengan 8,03 persen dari seluruh penduduk Indonesia tahun 2014. Jumlah lansia perempuan lebih besar daripada laki-laki, yaitu 10,77 juta lansia perempuan dibandingkan 9,47 juta lansia laki-laki. Nilai rasio ketergantungan lansia sebesar 12,71 menunjukkan bahwa setiap 100 orang penduduk usia produktif harus menanggung sekitar 13 orang lansia (Badan Pusat Statistik, 2014).

Struktur ageing population merupakan cerminan dari semakin tingginya rata-rata Usia Harapan Hidup (UHH) penduduk Indonesia. Tingginya UHH merupakan salah satu indikator keberhasilan pencapaian pembangunan nasional terutama di bidang kesehatan. Sejak tahun 2004 - 2015 memperlihatkan adanya peningkatan Usia Harapan Hidup di Indonesia dari 68,6 tahun menjadi 70,8 tahun dan proyeksi tahun 2030-2035 mencapai 72,2 tahun (Kemenkes, 2016).

Peningkatan umur harapan hidup membuat pemerintah perlu merumuskan kebijakan dan program yang ditujukan kepada kelompok penduduk lansia sehingga dapat berperan dalam pembangunan dan tidak menjadi beban bagi masyarakat. Undang-Undang Nomor 13 Tahun 1998 tentang kesejahteraan lansia menetapkan, bahwa batasan umur lansia di Indonesia adalah 60 tahun ke atas (Kemenkes, 2014). Pemerintah melakukan upaya peningkatan dan pemerataan layanan kesehatan melalui posyandu lansia untuk menurunkan masalah kesehatan lanjut usia dan meningkatkan ketersediaan fasilitas pelayanan lanjut usia. Pos Pelayanan Terpadu (Posyandu) Lanjut Usia merupakan suatu wadah pelayanan kepada lanjut usia di masyarakat, yang proses pembentukan dan pelaksanaannya dilakukan oleh masyarakat bersama lembaga swadaya masyarakat (LSM), lintas sektor pemerintah dan nonpemerintah dan swasta (Kemenkes, 2016).

Indikator keberhasilan yang diharapkan pada tahun 2014 di 33 provinsi dapat mengembangkan program kesehatan lansia, indikator yang diharapkan terdiri dari $90 \%$ kabupaten/kota dapat mengembangkan program kesehatan lansia, $70 \%$ puskesmas dapat melaksanakan program lansia, 70\% lansia mendapatkaan pelayanan kesehatan, $40 \%$ pra lansia mendapatkan pelayanan kesehatan dan $100 \%$ lansia mendapatkan pelayanan kesehatan di panti Werdha (Kemenkes RI, 2012). Pencapaian indikator untuk meningkatkan keberhasilan pelaksaan program Posyandu Lansia harus 
diimbangi dengan adanya peran kader karena kader sebagai pihak yang menjadi penyambung program pemerintah demi terlaksananya semua program-program yang ada di Posyandu Lansia. Peran kader secara umum demi terlaksananya program Posyandu Lansia terdiri dari sebagai penggerak masyarakat, pemantauan dan penyuluhan (Kemenkes, 2010).

Faktor yang mempengaruhi peran kader dalam melaksanakan posyandu lansia yaitu umur, sikap, motivasi, pengetahuan, masa kerja, pendidikan, pekerjaan, insentif/penghargaan dan pelatihan. Penelitian yang dilakukan Setyoadi, dkk (2014) didapatkan bahwa terdapat hubungan antara peran kader dengan peningkatan kualitas hidup lansia. Hal ini menunjukkan bahwa peran kader juga sangat penting dalam Posyandu Lansia.

Data Dinas Kesehatan Kota Bengkulu Tahun 2015, jumlah lansia usia 60 tahun keatas sebanyak 15.057orang (48\%) dari 31.250 jumlah penduduk kota. Lansia yang mendapat pelayanan kesehatan sebanyak $4.248(57,19 \%)$ untuk laki-laki dan $4.506 \quad(59,15 \%)$ untuk perempuan (Dinas Kesehatan Kota Bengkulu, 2015). Studi pendahuluan yang dilakukan di Puskesmas Jalan Gedang proporsi jumlah lansia yang mendapatkan pelayanan kesehatan menempati urutan ketiga setelah Puskesmas Sidomulyo dan Padang Serai. Cakupan pelayanan kesehatan lansianya sebanyak (81,92\%) dan jumlah lansia sebanyak 686 orang (Dinas Kesehatan Kota Bengkulu, 2015). Kunjungan lansia yang datang ke posyandu berkisar 41-53 orang per bulan pada tahun 2016.

Puskesmas Jalan Gedang memiliki dua Posyandu Lansia terdiri dari Posyandu
Lansia Serayu Mandiri dan Posyandu Lansia Damai. Posyandu ini memiliki lima orang kader dan pesertanya 44 orang. Posyandu Lansia Serayu Mandiri memiliki kegiatan rutin pelaksanaan Posyandu Lansia sebulan sekali. Posyandu Lansia Damai ini memiliki kader lima orang, peserta lansianya ada 50 orang. Posyandu Lansia Damai memiliki kegiatan setiap minggu seperti senam, kegiatan keagamaan, jumat bersih. Posyandu Lansia Damai ini pernah mendapatkan tiga piagam penghargaan. Tahun 2015 mendapatkan Juara 2 Lomba Puskesmas Bengkulu Unggulan Tingkat Kota Bengkulu dan juara 1 Lomba Binaan Keluarga Lansia Tingkat Provinsi. Tahun 2016 mendapatkan piagam penghargaan Pengembangan Kapasitas SDM Pengelola Bina Keluarga Lansia Se-Provinsi Bengkulu.

Data tersebut menunjukkan kedua Posyandu di Puskesmas Jalan Gedang memiliki perbedaan baik dalam segi prestasi dan juga program yang dimiliki. Peran kader pada Posyandu Lansia Serayu Mandiri seharusnya lebih giat untuk bisa menyeimbangkan prestasi dan program yang dimiliki oleh Posyandu Lansia Damai. Padahal kedua posyandu mendapatkan binaan yang sama dari pihak Puskesmas. Penelitian ini bertujuan untuk mengetahui faktor yang mempengaruhi peran kader dalam pelayanan Posyandu Lansia di Wilayah Binaan Puskesmas Jalan Gedang Kota Bengkulu.

\section{BAHAN DAN CARA KERJA}

Desain penelitian yang digunakan pada penelitian ini adalah deskriptif dengan metode kualitatif. Informan pada penelitian ini yaitu sebanyak 10 orang kader dan 1 orang petugas penanggung 
jawab program posyandu lansia. Desain penelitian yang digunakan pada penelitian ini adalah deskriptif dengan metode kualitatif.

\section{HASIL}

Tabel 1. Karateristik Umur Kader di Posyandu Lansia Serayu Mandiri dan Posyandu Lansia Damai

\begin{tabular}{ccc}
\hline Posyandu & Frekuensi & \% \\
\hline Posyandu Damai & & \\
40-50 tahun & 2 & 40 \\
50-60 tahun & 2 & 40 \\
$>60$ tahun & 1 & 20 \\
Posyandu Serayu Mandiri & & \\
40-50 tahun & 3 & 60 \\
50-60 tahun & 2 & 40 \\
$>60$ tahun & 0 & 0 \\
& & \\
\hline
\end{tabular}

Hasil penelitian didapatkan bahwa karateristik umur kader Posyandu Damai hampir sebagian (40\%) memiliki umur 4050 tahun dan 50-60 tahun, sebagian besar (60\%) kader Posyandu Serayu Mandiri memiliki umur 40-50 tahun.

Tabel 2. Karateristik Pendidikan Kader di Posyandu Lansia Serayu Mandiri dan Posyandu Lansia Damai

\begin{tabular}{lcl}
\hline Posyandu & Frekuensi & $\%$ \\
\hline Posyandu Damai & & \\
SMP & 0 & 0 \\
SMA/SMK/SMEA & 4 & 80 \\
S2 & 1 & 20 \\
Posyandu Serayu Mandiri & & \\
SMP & 1 & 20 \\
SMA/SMK/SMEA & 4 & 80 \\
S2 & 0 & 0 \\
\hline
\end{tabular}

Hasil penelitian pada tabel 2 . didapatkan bahwa hampir seluruh $(80 \%)$ kader Posyandu Damai menamatkan pendidikan SMA/SMK/SMEA dan hampir seluruh $(80 \%)$ kader Posyandu Serayu Mandiri menamatkan pendidikan SMA/SMK/SMEA.

Hasil penelitian tabel 3. didapatkan bahwa hampir seluruh $(80 \%)$ kader Posyandu Damai bekerja sebagai IRT dan seluruh (100\%) kader Posyandu Serayu Mandiri bekerja sebagai IRT

Tabel 3. Karateristik Pekerjaan Kader di Posyandu Lansia Serayu Mandiri dan Posyandu Lansia Damai

\begin{tabular}{ccc}
\hline Posyandu & Frekuensi & \% \\
\hline Posyandu Damai & & \\
IRT & 4 & 80 \\
Pensiunan & 1 & 20 \\
Posyandu Serayu Mandiri & & \\
IRT & 5 & 100 \\
Pensiunan & 0 & 0 \\
\hline
\end{tabular}

Tabel 4. Karateristik Lama Menjadi Kader di Posyandu Lansia Serayu Mandiri dan Posyandu Lansia Damai

\begin{tabular}{lcc}
\hline Posyandu & Frekuensi & \% \\
\hline Posyandu Damai & & \\
2 tahun & 2 & 40 \\
4-6 tahun & 1 & 20 \\
9-12 tahun & 2 & 40 \\
Posyandu Serayu Mandiri & & \\
2 tahun & 4 & 80 \\
4-6 tahun & 1 & 20 \\
9-12 tahun & 0 & 0 \\
\hline
\end{tabular}

Hasil penelitian pada tabel 4 didapatkan bahwa hampir sebagian (40\%) kader Posyandu Damai lama menjadi kader 2 tahun dan 9-12 tahun. Kemudian, hampir seluruh (80\%) kader Posyandu Serayu Mandiri lama menjadi kader 2 tahun.

\section{Pengetahuan Kader}

Hasil penelitian dari 10 orang kader didapatkan hasil wawancara mengenai pengetahuan sebagai berikut :

\section{Posyandu Lansia Damai}

Hasil wawancara yang dilakukan kepada 5 informan di Posyandu Lansia Damai didapatkan hasil bahwa pengetahuan mereka mengenai pengertian posyandu lansia sudah baik, sebagian besar menjawab untuk rentang umur pada Posyandu Lansia menjawab bahwa rentang umur Posyandu Lansia 60 tahun keatas seperti hasil wawancara berikut : "Posyandu lansia merupakan tempat berkumpulnya lansia yang umurnya 60 tahun (Posyandu lansia merupakan tempat 
berkumpulnya lansia yang umurnya 60 tahun) (Informan 1).

Namun, ada 1 informan yang menjelaskan pengertian Posyandu Lansia tanpa menyebutkan rentang umur untuk Posyandu Lansia “ E....istilah posyandu lansia adalah wadah berkumpulnya usia lanjut juga untuk meningkatkan kesehatan dan meningkatkan keterampilan pengetahuan kesehatan " (Istilah posyandu lansia adalah wadah berkumpulnya usia lanjut untuk meningkatkan kesehatan dan meningkatkan keterampilan kesehatan) (Informan 4).

Selanjutnya, untuk tujuan sebagian besar dari mereka menjawab bahwa tujuan digunakan sebagai wadah untuk berobat lansia sebagai kutipan wawancara berikut:

"Tujuan posyandu lansia intinyo untuk wadah bagi lansia bisa berobat, bisa memeriksakan kesehatan dan bertemu dengan kelompok-kelompok lansia yang lain” (Tujuan posyandu lansia untuk wadah bagi lansia untuk bisa berobat, bisa memeriksakan kesehatan dan bertemu dengan kelompok-kelompok lansia yang lain) ( Informan 1)

Selain itu, ada juga yang mengatakan bahwa tujuan posyandu lansia untuk meningkatkan derajat kesehatan lansia seperti kutipan wawancara berikut :

"Tujuan posyandu lansia untuk meningkatkan derajat kesehatan dan juga untuk pencegahan penyakit usia lanjut" (Tujuan posyandu lansia untuk meningkatkan derajat kesehatan dan juga untuk pencegahan penyakit usia lanjut) (Informan 2)

Hasil wawancara didapatkan bahwa sebagian informan menjawab bahwa manfaat posyandu lansia meningkatkan status kesehatan, meningkatkan derajat kesehatan dan meningkatkan usia harapan seperti kutipan wawancara berikut :

"Manfaat meningkatkan status kesehatan lansia, meningkatkan derajat kesehatan, memperlambat proses penuaan, deteksi kesehatan dan meningkatkan usia harapan" (Manfaat meningkatkan status kesehatan lansia, meningkatkan derajat kesehatan, memperlambat proses penuaan, deteksi kesehatan dan meningkatkan usia harapan) (Informan 2).

\section{Posyandu Lansia Serayu Mandiri}

Pada Posyandu Lansia Serayu Mandiri sebagian besar dari mereka menjawab bahwa Posyandu Lansia rentang umur 40 tahun keatas seperti hasil wawancara berikut:

"Yo...suatu tempat wadah berkumpul para lansia 40 tahun ke atas dek" (Posyandu lansia merupakan tenmpat berkumpul lansia dengan umur 40 tahun keatas) (Informan 7).

Kemudian, untuk tujuan mereka mengatakan bahwa Posyandu lansia untuk meningkatkan derajat kesehatan lansia seperti hasil wawancara berikut:

"Untuk kesehatan tubuh, untuk meningkatkan kesehatan tubuh usia lanjut" (Untuk kesehatan tubuh, untuk meningkatkan tubuh usia lanjut)

(Informan 6).

Manfaat Posyandu Lansia mereka mengatakan untuk meningkatkan usia harapan hidup dan memperlambat proses penuaan seperti hasil wawancara berikut:

"Meningkatkan usia harapan hidup, memperlambat proses penuaan dini dan pengecekan kesehatan" (Meningkatkan usia harapan hidup, memperlambat proses penuaan dini dan pengecekan kesehatan) (Informan 6)

Kemudian, ada juga yang menyatakan bahwa manfaat Posyandu Lansia untuk berobat, ikut senam dan menambah pengetahuan seperti kutipan wawancara berikut :

"untuk perikso kesehatannya tiap bulan" (untuk memeriksakan kesehatannya tiap bulan) (Informan 8)

Namun, ada kader yang mengatakan bahwa untuk mengetahui penyakit lansia dan segera bisa diberi tindak lanjut seperti hasil wawancara berikut:

"biar kalau ada penyakit cepat diketahui dan diberi obat, itulah sepengetahuan aku 
buk" (biar kalau ada penyakit cepat diketahui dan diberi obat) (Informan 10)

Setelah dilakukan hasil wawancara dengan petugas puskesmas didapatkan data bahwa posyandu lansia merupakan wadah bagi para lansia untuk mendapatkan pelayanan kesehatan dengan sasarannya pra lansia (usia 45 - 59 tahun), lansia (usia 60 -69 tahun) dan lansia resiko tinggi (usia $>70$ tahun). Didirikannya Posyandu Lansia ada dua tujuan yaitu tujuan khusus dan tujuan umum. manfaat dari posyandu lansia adalah meningkatkan status kesehatan lansia, meningkatkan kemandirian pada lansia, memperlambat aging proses, deteksi dini gangguan kesehatan pada lansia dan meningkatkan usia harapan hidup.

\section{Sikap Kader}

\section{Posyandu Lansia Damai}

Sikap kader dalam melakukan Posyandu Lansia dalam penelitian ini sudah sangat mendukung dalam melaksanakan Posyandu, sebagian besar dari kader sudah memberikan penyuluhan secara teratur setiap kegiatan Posyandu dan membuat laporan setiap bulan yang diserahkan kepada pihak Puskesmas, seperti kutipan wawancara berikut : " $D i$ kegiatan posyandu lansia kita memberikan penyuluhan secara teratur, setiap akhir kegiatan kito buat laporan " (Di kegiatan posyandu lansia kite memberikan penyuluhan secara teratur, setiap akhir kegiatan kita membuat laporan) (Informan 2). "Iyalah teratur setiap bulan, setiap kegiatan diberikan penyuluhan

Namun, ada juga kader yang mempunyai sikap tidak mendukung dalam hal melakukan pemberian penyuluhan berdasarkan hasil wawancara berikut : "Kalau kami kadang-kadang memberikan penyuluhan, kalau laporan ditulis setiap kegiatan langsung dibawa ke petugas Puskesmas" (Kalau kami kadang-kadang memberikan penyuluhan, kalau laporan ditulis setiap kegiatan langsung dibawa ke petugas Puskesmas) (Informan 1).

\section{Posyandu Lansia Serayu Mandiri}

Sebagian kader sudah melakukan penyuluhan secara tertaur setiap bulan, seperti kutipan wawancara berikut: "Penyuluhannya teratur, dilaporkan setiap waktu sesudah Posyandu" (Penyuluhannya teratur, laporan dilaporkan setiap sesudah Posyandu) (Informan 6).

Namun, ada juga kader yang belum berani memberikan penyuluhan seperti kutipan wawancara berikut: "sayo belum berani buk memberikan penyuluhan, takut salah sayo buk. Laporan langsung kami rekap buk setelah kegiatan" (saya belum berani untuk memberikan penyuluhan, takut salah. Laporannya saya rekap setiap selesai kegiatan (Informan 8, 10)

Hasil ini dibenarkan oleh Petugas Puskesmas bahwa penyuluhan kepada lansia harus diberikan secara teratur setiap bulan kegiatan Posyandu Lansia dan pembuatan laporan dilakukan segera setelah selesai kegiatan Posyandu sehingga bisa dilakukan perekapan oleh petugas Puskesmas.

\section{Motivasi kader}

Hasil penelitian didapatkan bahwa para kader bersedia untuk menjadi kader dalam Posyandu Lansia atas alasan sosial seperti kutipan wawancara berikut :

\section{Posyandu Lansia Damai}

"Untuk sosialisasi dan untuk membantu para lansia supaya bisa memeriksakan kesehatannya tiap bulan"(Untuk sosialisasi dan membantu para lansia supaya bisa memeriksakan kesehatannya setiap bulan) (Informan 4).

\section{Posyandu Lansia Serayu Mandiri}

Motivasi kader dalam menjadi kader Posyandu Lansia karena ingin kumpul setiap bulan dan mengisi kegiatan di waktu luang seperti kutipan wawancara berikut: "Motivasinyo tu biar kumpul samo temanteman yang seusia kita bu, biar menambah pengetahuan dari satu ke yang satu Motivasinya bisa kumpul sama-sama 
teman yang seusia, menambah pengetahuan dari satu ke yang satu) (Informan 6).

\section{Peran Kader \\ Posyandu Lansia Damai}

Hasil wawancara didapatkan bahwa peran kader sebagai penggerak, penyuluhan dan pemantauan didapatkan pada kutipan wawancara sebagai berikut :

"Membantu memberikan penjelasan tentang kesehatan kepada usia lanjut supaya bisa mengikuti kegiatan seperti pengecekan kesehatan, sebagai penggerak lansia misalnya seperti pendampingan keluarga sadar gizi dan memberikan penjelasan tentang kesehatan seperti senam lansia" (Membantu memberikan penjelasan tentang kesehatan kepada usia lanjut supaya bisa mengikuti kegiatan seperti pengecekan kesehatan, sebagai penggerak lansia misalnya seperti pendampingan keluarga sadar gizi dan memberikan penjelasan tentang kesehatan seperti senam lansia) (Informan 5).

Kemudian, sebagian kader juga menjawab bahwa untuk peran kader sebagai mengajak lansia untuk ikut posyandu lansia sehingga bisa melakukan pemantauan kesehatan lansia seperti kutipan berikut :

“ Kalau peran kader mengajak lansia untuk ikut posyandu lansia, memberikan penyuluhan sebelumnya menyiapkan alatalat keperluan posyandu " (Kalau peran kader mengajak lansia untuk ikut posyandu lansia, memberikan penyuluhan sebelumnya menyiapkan alat-alat keperluan posyandu) (Informan 1).

\section{Posyandu Lansia Serayu Mandiri}

Sebagian kader menjawab bahwa peran kader untuk Posyandu lansia adalah mengajak lansia untuk ikut Posyandu dan menyiapkan pelaksanaan Posyandu Lansia sesuai dengan hasil kutipan berikut:

"yo, kalau menurut sayo itu perannya ngajak ibu-ibu rukun tetangga untuk pegi ke posyandu lansia untuk memberikan penjelasan tentang senam lansia" (kalau menurut saya peran kader itu mengajak ibu-ibu rukun tetangga untuk pergi ke Posyandu Lansia untuk memberikan penjelasan tentang senam lansia) (Informan 6).

Secara umum para kader sudah mengetahui peran kader, namun tidak secara spesifik. Petugas Puskesmas mengatakan bahwa peran kader terdiri dari tiga yaitu sebagai penggerak masyarakat, penyuluhan dan melakukan pemantauan.

\section{Insentif/Reward}

Hasil wawancara didapatkan bahwa sebagian besar dari kader belum mendapatkan insentif/reward seperti kutipan wawancara sebagai berikut:

\section{Posyandu Lansia Damai}

"Yang diperoleh nggak ada, kalau reward/imbalan kadang kadang ada, kadang-kadang nggak, kalau masalah cukup atau tidak, pasti saya tidak cukup. Tapi disini kami tidak begitu mengharapkannya bu, yang penting posyandu ini bisa berjalan " (Yang diperoleh tidak ada, kalau reward/imbalan kadang-kadang ada kadang-kadang tidak, kalau masalah cukup atau tidak, pasti saya tidak cukup. Tetapi kami disini tidak begitu mengharapkanya, yang penting posyandu ini bisa berjalan) (Informan 1).

Namun, sebagian mereka juga mengatakan bahwa mereka tidak mengharapkan reward karena mereka bekerja secara sukarela dan untuk kebutuhan sosial seperti kutipan wawancara berikut:

"Ya saya kira menurut saya ini kegiatan sosial, kita tidak mengharapkan adanya insentif

(Saya kira ini kegiatan sosial, kita tidak mengharapkan adanya insentif) (Informan2). "Kalo reward kami belum ada, tapi kalau penghargaan di posyandu lansianya ada, kalo setiap kader-kadernya belum, kalo gaji bulanannya sifatnya sosial aja, kerja-kerja kami tukan sosial, sukarela”. 
(Kalau reward setiap kader kami belum ada, tapi kalau penghargaan untuk posyandu lansia ada, kalau untuk gaji bulanan sifatnya sosial saja, karena kami bekerja untuk sosial dan secara sukarela (Informan 3).

\section{Posyandu Lansia Serayu Mandiri}

Pemberian insentif/reward tidak terlalu diharapkan oleh kader, karena tujuan mereka ikut dalam Posyandu adalah kegiatan sosial seperti hasil kutipan wawancara berikut: "Ya kalau ada tu kami bersyukur, ya kalau dibilang nggak cukup, Cuma kita kerjanya sukarela saja, kalau dikasih ya diambil, kalau enggak dikasih gak papa" ( Kalau ada kami bersyukur, kalau dibilang tidak cukup, Cuma kita kerjanya sukarela, kalau dikasih diambil, kalau tidak dikasih tidak apa-apa) (Informan 6).

Petugas Puskesmas membenarkan bahwa tidak ada- isnentif/reward yang diberikan secara perorang kepada kader, namun untuk meningkatkan peran kader ada satu wadah yang bisa digunakan untuk mendapatkan reward yaitu lomba Posyandu Lansia. Ini bisa dijadikan wadah dalam mendapatkan reward tapi dalam bentuk kelompok.

\section{Pelayanan Posyandu Lansia Posyandu Lansia Damai}

Hasil penelitian didapatkan bahwa responden menyebutkan sistem lima meja dengan benar kutipan wawancara sebagai berikut:"Meja pertama itu pendaftaran

\section{PEMBAHASAN}

\section{Umur}

Hasil penelitian didapatkan bahwa karateristik umur kader Posyandu Damai hampir sebagian (40\%) memiliki umur 4050 tahun dan 50-60 tahun, sebagian besar $(60 \%)$ kader Posyandu Serayu Mandiri memiliki umur 40-50 tahun. Karateristik umur kedua Posyandu tidak terdapat perbedaan yang terlalu signifikan. registrasinyo, meja kedua penimbangan dan tensi, meja ketiga pencatatan buku kesehatan , meja empat konsultasi pelayanan dan meja lima pencatatan" (Meja pertama itu pendaftaran registrasinya, meja kedua penimbangan dan tensi, meja ketiga konsultasi pelayanan, meja empat pemeriksaan dan meja lima pencatatan) (Informan 2)

Kemudian, ada juga kadr yang tidak mengetahui mengenai pelayanan posyandu lima meja seperti kutipan wawancara berikut:

"Meja pertama pencatatan, meja kedua pendaftaran, meja ketiga pengecekan, meja keempat pengobatan, meja kelima pencatatan hasil" (Meja pertama pencatatan, meja kedua pendaftaran, meja ketiga pengecekan, meja keempat pengobatan, meja kelima pencatatan hasil) (Informan 3)

a. Posyandu Lansia Serayu Mandiri

Kader dalam Posyandu Lansia Serayu Mandiri tidak ada yang mengetahui mengenai sistem pelayanan Posyandu Lima Meja seperti kutipan wawancara berikut: "belum hapal bu, pertama tu pendaftaran, baru dicatat, diperikso, diobati, terakhir penyuluhan, itulah kalau 5 meja tu buk" (belum hapal bu, pertama pendaftaran, dicatat, diperiksa, diobati, seperti itu sistem 5 meja buk) (Informan 10)

Umur pada masa ini termasuk dalam masa dewasa dimana dengan usia dewasa diharapkan mampu menjadi kader yang memiliki jiwa sosial yang tinggi kepada masyarakat, serta memikul tanggung jawab sebagai penggerak posyandu dan dapat menyampaikan informasi tentang kesehatan pada masyarakat (Wahyutomo, 2010).

Penelitian yang dilakukan Hapsari (2015) berdasarkan hasil dari uji Chi 
Square dengan Expected Count 5,70 didapatkan hasil bahwa dengan nilai $p$ value lebih kecil dari 0,05 ( $p$ value 0,034 < $0,05)$ berati Ho ditolak dan $\mathrm{Ha}$ diterima yang artinya ada hubungan antara umur dengan keaktifan kader posyandu, bahwa umur merupakan faktor yang sangat penting bagi seorang kader dalam menjalankan posyandu, semakin bertambahnya umur semakin akan aktif dalam berkegiatan karena mempunyai pengalaman yang baik dan lebih mudah menjalankan tugas dan peran sebagai kader posyandu.

\section{Pendidikan}

Hasil penelitian didapatkan bahwa hampir seluruh (80\%) kader Posyandu Damai menamatkan pendidikan SMA/SMK/SMEA dan hampir seluruh $(80 \%)$ kader Posyandu Serayu Mandiri menamatkan pendidikan SMA/SMK/SMEA. Pendidikan kedua posyandu juga tidak terdapat perbedaan. Pendidikan adalah dasar untuk menyiapkan peserta didik melalui kegiatan bimbingan pengajaran dan latihan bagi perannya dimasa yang akan datang (UU. RI No.20, Tahun 2003).

\section{Pekerjaan}

Hasil penelitian didapatkan bahwa hampir seluruh (80\%) kader Posyandu Damai bekerja sebagai IRT dan seluruh $(100 \%) \quad$ kader Posyandu Serayu Mandiribekerja sebagai IRT. Pekerjaan merupakan sarana bagi manusia untuk merealisasikan apa yang ada dalam pikirannya dan diartikan sebagai aktivitas rutin yang dilakukan untuk memperoleh pendapatan (Firmansyah, 2012).

Pekerjaan berkaitan dengan waktu yang dimiliki kader untuk melakukan kegiatan di luar rumah. Penelitian yang dilakukan Suhat dan Ruyatul Hasanah (2014) Hasil uji statistik menunjukkan P Value $=0,0005$ lebih kecil dari nilai $\alpha$ $(0,05)$ maka disimpulkan bahwa terdapat hubungan pekerjaan kader dengan keaktifan kader dalam kegiatan posyandu di Wilayah kerja Puskesmas Palasari Kecamatan Ciater Kabupaten Subang. Hasil statistik didapatkan nilai POR $(95 \%$ CI $=12,75(4,033-40,309)$, artinya bahwa kader yang tidak bekerja akan mempunyai resiko untuk aktif sebesar 12,75 kali dibandingkan kader yang bekerja.

\section{Lama Menjadi Kader}

Hasil penelitian didapatkan bahwa hampir sebagian $(40 \%)$ kader Posyandu Damai lama menjadi kader 2 tahun dan 912 tahun. Kemudian, hampir seluruh $(80 \%)$ kader Posyandu Serayu Mandiri lama menjadi kader 2 tahun. Lama menjadi kader kedua Posyandu terdapat perbedaan, pada Posyandu Damai ada kader yang menjadi kader 9-12 tahun. Lama menjadi kader berkaitan dengan pengalaman dalam melakukan peran sebagai kader. Semakin lama menjadi kader akan semakin baik dalam melakukan perannya sebagai kader.

\section{Pengetahuan Kader}

Pengetahuan merupakan kemampuan seseorang yang mempengaruhi terhadap tindakan yang dilakukan. pengetahuan seseorang tidak secara mutlak dipengaruhi oleh pendidikan karena pengetahuan dapat juga diperoleh dari pengalaman masa lalu, namun tingkat pendidikan turut pula menentukan mudah tidaknya seseorang menyerap dan memahami informasi yang diterima yang kemudian menjadi dipahami (Notoatmodjo, 2010).

Hasil wawancara didapatkan kader pada Posyandu Lansia Damai mengatakan bahwa Posyandu Lansia berada pada rentang umur 60 tahun keatas. Tujuan Posyandu Lansia untuk meningkatkan kesehatan dan wadah berobat lansia. Manfaat Posyandu Lansia dikatakan untuk meningkatkan derajat kesehatan dan tempat berobat.

Hasil wawancara kader Posyandu Lansia Serayu mandiri menyebutkan bahwa Posyandu Lansia Serayu Mandiri rentang umur 40 tahun keatas. Tujuan Posyandu Lansia meningkatkan kesehatan dan memperlambat proses penuaan. 
Manfaat Posyandu Lansia untuk meningkatkan usia harapan hdiup dan wadah berobat bagi para lansia.

Hasil wawancara kedua kelompok menunjukkan perbedaan dalam segi hal rentang umur usia. Teori yang dikemukakan Notoatmodjo (2012) posyandu lansia merupakan wahana pelayanan bagi kaum- lansia yang dilakukan dari, oleh dan untuk kaum lansia yang menitikberatkan pelayanan kesehatan upaya promotif dan preventif, tanpa mengabaikan upaya kuratif dan rehabilitative. Kemudian, sasaran umur pada Posyandu Lansia sasarannya pra lansia (usia 45 - 59 tahun), lansia (usia 60 -69 tahun) dan lansia resiko tinggi (usia > 70 tahun).

Menurut Kemenkes (2010) bahwa posyandu lansia memiliki tujuan umum dan tujuan khusus. Tujuan umum dibentuknya posyandu lansia untuk meningkatkan derajat kesesehatan dan mutu kehidupan lansia demi mencapai masa tua yang bahagia dan bergaya guna dalam kehidupan keluarga dan masyarakat sesuai dengan keberadaanya.

Sedangkan tujuan khusus pembentukan posyandu lansia adalah memelihara kesadaran pada lanjut usia untuk membina sendiri kesehatannya, meningkatkan kemampuan dan peran serta keluarga dan masyarakat dalam menghayati dan menghargai kesehatan lansia, meningkatkan jenis dan jangkauan pelayanan kesehatan lansia, meningkatkan mutu pelayanan kesehatan lansia, membina lansia dalam bidang kesehatan fisik spiritual, sebagai sarana untuk menyalurkan minat lansia, meningkatkan rasa kebersamaan diantara lansia dan meningkatkan kemampuan lansia untuk mengembangkan kegiatan kesehatan dan kegiatan - kegiatan lain yang menunjang sesuai dengan kebutuhan.

Sama halnya dengan pengetahuan mengenai manfaat Posyandu Lansia hanya sebatas tahu saja, tetapi tidak mengetahui secara detail. Teori menurut Azizah
(2011), manfaat dari posyandu lansia adalah meningkatkan status kesehatan lansia, meningkatkan kemandirian pada lansia, memperlambat aging proses, deteksi dini gangguan kesehatan pada lansia dan meningkatkan usia harapan hidup.

\section{Sikap Kader}

Hasil penelitian didapatkan bahwa Posyandu Lansia Damai memiliki sikap kader yang mendukung. Terdapat perbedaan dengan kader Posyandu Lansia Serayu Mandiri bahwa ada kader yang tidak mendukung, hal ini bisa dilihat dari ada kader yang tidak memberikan penyuluhan.

Sikap kader yang positif dan mendukung akan membuat para lansia bisa tertarik untuk mengikuti Posyandu Lansia seperti penelitian yang dilakukan Penelitian Hasugian (2012) didapatkan bahwa bahwa responden yang memiliki sikap yang baik, banyak yang memanfaatkan Posyandu Lansia sedangkan responden yang memiliki sikap yang kurang, banyak diantaranya kurang memanfaatkan Posyandu Lansia. Oleh karena itu, semakin baik sikap lansia tentang pemanfaatan Posyandu Lansia, maka akan semakin baik keikutsertaan lansia dalam pemanfaatan Posyandu Lansia.

\section{Motivasi kader}

Hasil penelitian dari kedua Posyandu yaitu Posyandu Damai dan Posyandu Serayu Mandiri didapatkan bahwa sebagian besar kader memiliki motivasi menjadi kader karena sosial dan untuk mengisi kegiatan luang dalam sehari-hari. Menurut Efendi (dalam Badeni, 2013) motivasi diartikan sebagai faktor-faktor yang mengarahkan dan mendorong prilaku atau keinginan seseorang untuk melakukan sesuatu kegiatan yang dinyatakan dalam bentuk usaha yang kuat atau lemah. Semakin positif motivasi seorang kader dalam menjalankan perannya, akan 
semakin bagus perannya dalam melaksanakan tugas.

Penelitian ini sejalan dengan penelitian Setyatama (2012) didapatkan bahwa ada hubungan yang bermakna antara motivasi kader dengan peran kader dalam kegiatan posyandu lansia di desa Kangkung kecamatan Mranggen kabupaten Demak tahun 2012. Hal ini diasumsikan bahwa kader yang mempunyai motivasi cukup tentang posyandu lansia akan tetap berperan baik dalam kegiatan posyandu lansia.

\section{Peran Kader}

Hasil wawancara didapatkan bahwa peran kader sebagai penggerak, penyuluhan dan pemantauan dan sebagian kader juga menjawab bahwa untuk peran kader sebagai mengajak lansia untuk ikut posyandu lansia. Teori yang dikemukakan Kemenkes RI (2010) mengemukakan bahwa peran kader terdiri dari tiga penggerakan masyarakat, penyuluhan, dan pemantauan.

Kader berperan menggerakan masyarakat untuk memberi pengaruh pada masyarakat dalam berperilaku sesuai harapan yang diinginkan. Jenis upaya penggerakan masyarakat yaitu: Upaya perbaikan gizi keluarga. Direktorat Bina Gizi Masyarakat (2010) menjelaskan upaya perbaikan gizi keluarga dapat dilakukan kader melalui pendampingan dengan upaya Keluarga Sadar Gizi.

Teknis penyuluhan yang dapat dilakukan oleh kader, baik secara perorangan ataupun kelompok adalah: Penyuluhan perorangan atau tatap muka: Penyuluhan perorangan dapat dilakukan di posyandu ataupun kunjungan rumah. Sedangkan penyuluhan kelompok merupakan penyuluhan yang dilakukan pada sasaran kelompok masyarakat. Kegiatan penyuluhan dimulai dengan penjelasan materi oleh kader dan dilanjutkan tanya jawab. Penyuluhan disertai peragaan yaitu kegiatan yang dilakukan kader bersama petugas untuk memberikan penyuluhan disertai peragaan seperti demonstrasi pembuatan makanan.

Kegiatan pemantauan mencakup telaah penyelenggaraan kegiatan dan hasil yang dicapai, baik itu telaah internal maupun telaah eksternal. Telaah internal adalah telaah bulanan terhadap penyelenggaraan kegiatan dan hasil yang dicapai oleh puskesmas dibandingkan dengan rencana dan standar pelayanan. Telaah eksternal adalah telaah triwulan terhadap hasil yang dicapai oleh sarana pelayanan kesehatan tingkat pertama lainnya serta sector lain terkait yang ada di wilayah kerja puskesmas.

\section{Insentif/Reward}

Insentif merupakan salah satu alasan bagi seseorang untuk bekerja dan mungkin merupakan alasan yang paling penting diantara yang lain seperti untuk berprestasi, mengembangkan diri dan atau mengaktualisasikan diri. Hasil penelitian didapatkan bahwa kader sebagian besar tidak mendapatkan insentif/reward. Pada penelitian ini kedua Posyandu tidak memiliki perbedaan dalam insentif karena motivasi mereka untuk menjadi kader bukan untuk mengharapkan imbalan, namun lebih untuk kebutuhan sosial dan mengisi kegiatan dalam sehari-hari.

Pemberian reward dapat meningkatkan partisipasi kader dalam melakukan tugasnya. Penelitian yang dilakukan Yanti (2013) bahwa kader yang memiliki dana insentif menunjukkan peluang berpartisipasi kader dalam pelaksanaan posyandu sebesar 6.090 kali di bandingkan dengan kader yang dana insentifnya tidak ada.

\section{KESIMPULAN}

Karateristik kader Posyandu Lansia Damai hampir sebagian memiliki umur 4050 tahun dan 50-60 tahun, hampir seluruh menamatkan pendidikan SMA/SMK/SMEA, hampir seluruh bekerja sebagai IRT dan hampir sebagian lama menjadi kader 2 tahun dan 9-12 tahun. Karateristik kader Posyandu Lansia Serayu 
Mandiri sebagian besar memiliki umur 4050 tahun, hampir seluruh menamatkan pendidikan SMA/SMK/SMEA, seluruh bekerja sebagai IRT dan hampir seluruh lama menjadi kader 2 tahun.

Pengetahuan kader Posyandu Lansia Damai didapatkan bahwa Posyandu Lansia untuk lansia rentang usia 60 tahun keatas dan kader Posyandu Lansia Serayu Mandiri bahwa Posyandu Lansia untuk rentang usia 40 tahun keatas. Sikap kader Posyandu Lansia Damai sebagian besar mendukung, tetapi Posyandu Lansia Serayu Mandiri sikap tidak mendukung.

\section{DAFTAR RUJUKAN}

Arifin, Zainal. 2014. Hubungan Peran Serta Kader Posyandu dengan Perawatan Hipertensi pada Lansia di Desa Salamrejo Sentolo Kulon Progo. [Skripsi]. Universitas Aisyiyah Yogyakarata Fakultas Ilmu Kesehatan Jurusan Keperawatan.

Azizah L. 2011. Keperawatan Lanjut Usia, Edisi 1. Yogyakarta: Graha Ilmu.

BPS. 2014. Survey Demografi Kesehatan Indonesia. Jakarta: Badan Pusat Statistik.

Carturiningsih, Rifa. 2013. Hubungan Pengetahuan Sikap dan Motivasi Kader dengan Kehadiran dalam Pelayanan Posyandu di Desa Tumpang Krasak. Jurnal Kesehatan dan Kebidanan (Journal of Midwifery And Health).

Depkes RI. 2006. Pedoman Pelatihan Kader Kelompok Usia Lanjut Bagi Petugas Kesehatan. Jakarta: Direktorat Kesehatan Keluarga.

Dinas Kesehatan Kota Bengkulu. 2015. Profil Dinas Kesehatan Kota Bengkulu. Bengkulu

Febriyani, Atika. 2015. Hubungan antara Peran Kader dengan Tingkat Kehadiran Lansia di Posyandu Lansia Wilayah Kerja Puskesmas Kesesi I Kabupaten Pekalongan. [Skripsi]. Program Studi Ners Sekolah Tinggi Ilmu Kesehatan Muhammadiyah Pekajangan Pekalongan

Hapsari, Tri Hanum. 2015. Faktor-Faktor Yang Berhubungan dengan Keaktifan Kader Posyandu di Wilayah Kerja Puskesmas Slawi Tahun 2015.

Hasugian, Hayani Putri. 2012. Hubungan Perilaku Lansia dan Dukungan Keluarga terhadap Pemanfaatan Posyandu Lansia di Wilayah Kerja Puskesmas Darussalam Tahun 2012.
Kader Posyandu Lansia Damai dan Posyandu Lansia Serayu Mandiri sebagian besar tidak mengharapkan insentif. Kader Posyandu Lansia Damai sebagian besar menyebutkan sistem lima meja dengan benar dan kader Posyandu Lansia Serayu Mandiri tidak ada yang menyebutkan sistem lima meja dengan tepat.

Diharapkan Puskesmas Jalan Gedang bisa melakukan penyegaran ataupun pelatihan kader agar pengetahuan kader mengenai posyandu lansia lebih baik, bisa meningkatkan peran dalam melakukan pelayanan posyandu lansia.

Kemenkes RI. 2014. Pedoman Pelaksanaan Posyandu Lansia. Komisi Nasional Lanjut Usia RI. Jakarta.

Kemenkes RI. 2016. Situasi Lanjut Usia (Lansia) di Indonesia. Pusat Data Informasi Kementerian Kesehatan Republik Indonesia. Jakarta.

Kementerian Kesehatan RI. 2012. Pedoman Penilaian Program Kesehatan Usia Lanjut bagi Petugas Kesehatan. Jakarta.

Kementerian Kesehatan RI.2011. Pedoman Umum Pengelolaan Posyandu. Jakarta

Kosasi, Siti Mutia dan Cecep Sobirin. 2014. Hubungan Pengetahuan tentang Posyandu Lansia dengan Kunjungan Posyandu pada Lansia di Wilayah Kerja Puskesmas Guguak Panjang Bukittinggi. Jurnal Kesehatan STIKes Prima Nusantara Bukittinggi, vol.5, no. 1.

Maisya, Iram Barida dan Gurendo Putro. 2015. Peran Kader dan Klian Adat dalam Upaya Meningkatkan Kemandirian Posyandu di Provinsi Bali (Studi Kasus di Kabupaten Badung, Gianyar, Klungkung dan Tabanan. Buletin Penelitian Sistem Kesehatan, 14(1):40-48.

Nisa, dkk. 2014. Hubungan Dukungan Keluarga Dan Peran Kader Dengan Keaktifan Lanjut Usia Dalam Mengikuti Kegiatan Di Posyandu Desa Pucangan Kartasura

Notoatmodjo S. 2010. Promosi Kesehatan dan Perilaku Kesehatan. Jakarta: Rineka Cipta.

Nteseo, Fitra Idris. 2014. Hubungan Pengetahuan, Sikap dan Motivasi Kader dengan Kinerja Kader Posyandu di Wilayah Kerja Puskesmas Tilango Kecamatan Tilango Kabupaten Gorontalo. [Skripsi]. Jurusan Ilmu Keperawatan Fakultas Ilmu-Ilmu 
Kesehatan dan Keolahragaan Universitas Negeri Gorontalo

Ratih Wirapuspita. 2013. Insentif dan Kinerja Kader Posyandu. Jurnal Kesehatan Masyarakat Kemas, 9(1):58-65.

Ria Afriani. 2011. Hubungan Pengetahuan Lansia dengan Pemanfaatan Posyandu Lansia Cengkeh di Wilayah Kerja Puskesmas Lubuk Begalung Padang Tahun 2011. Karya Tulis Ilmiah. STIKes Amanah Padang.

Setyatama, Ike Putri. 2012. Hubungan Pengetahuan dan Motivasi Kader dengan Peran Kader Posyandu Lansia di Desa Kangkung Kecamatan Mranggen Kabupaten Demak. Jurnal Dinamika Kebidanan vol. 2 no 2. Agustus 2012.

Setyoadi, Ahsan dan Alif Yanuar Abidin. 2014. Hubungan Peran Kader Kesehatan dengan
Tingkat Kualitas Hidup Lanjut Usia. Jurnal Ilmu Keperawatan. 1(2).

Wahono Hesthi. 2010. Analisis Faktor-Faktor yang Mempengaruhi Pemanfaatan Posyandu Lansia di Gantungan Makamhaji. [Skripsi]. Fakultas Ilmu Kesehatan Universitas Muhammdiyah Surakarta.

Yanti. 2013. Pengetahuan, Dana Insentif, Sarana dan Prasarana dengan Partisipasi Kader dalam Pelaksanaan Posyandu. Jurnal Ilmu Keperawatan.

Yuliana. 2011. Faktor yang Berhubungan dengan Kepatuhan Lansia dalam Mengikuti Pelayanan Posyandu Lansia di Desa Egon Kecamatan Wagete Kabupaten Sikka Propinsi NTT. [Skripsi]. Jurusan Kesehatan Reproduksi Sekolah Tinggi Ilmu Kesehatan Makassar. 